\title{
Material Selection for Multi-Function Waste Tank Facility Tanks
}

Prepared for the U.S. Department of Energy Office of Environmental Restoration and Waste Management

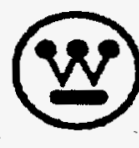
Westinghouse Hanford Company Richland, Washington

Hanford Operations and Engineering Contractor for the U.S. Department of EnergY under Contract DE-AC06-87RL10930

Copyright License By acceptance of this artide, the publisher and/or recipient acknowledges the U.S. Government's right to retain a nonexclusive, toyalty-free license in and to any copyright covering this paper.

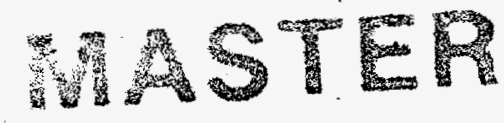

Approved for Public Release 
LEGAL DISCLAIMER

This report was prepared as an account of work sponsored by an agency of the United States Government. Neither the United States Government nor any agency thereof, nor any of their employees, nor any of their contractors, subcontractors or their employees, makes any warranty, express or implied, or assumes any legal liability or responsibility for the accuracy, completeness, or any third party's use or the results of such use of any information, apparatus, product, or process disclosed, or represents that its use would not infringe privately owned rights. Reference herein to any specific commercial product, process, or service by trade name, trademark, manufacturer, or otherwise, does not necessarily constitute or imply its endorsement, recommendation, or favoring by the United States Government or any agency thereof or its contractors or subcontractors. The views and opinions of authors expressed herein do not necessarily state or reflect those of the United States Government or any agency thereof.

This report has been reproduced from the best available copy.

Printed in the United States of America

DISCLM-2.CHP (1-91) 


\section{DISCLAIMER}

Portions of this document may be illegible in electronic image products. Images are produced from the best available original document. 


\title{
Material Selection for Multi- Function Waste Tank Facility Tanks
}

\author{
A. P. Larrick \\ Date Published \\ March 1995 \\ To Be Presented at \\ CORROSION/95 \\ Houston, Texas \\ March 26, 1995 \\ To Be Published in \\ NACE INTERNATIONAL
}

Prepared for the U.S. Department of Energy Office of Environmental Restoration and Waste Management

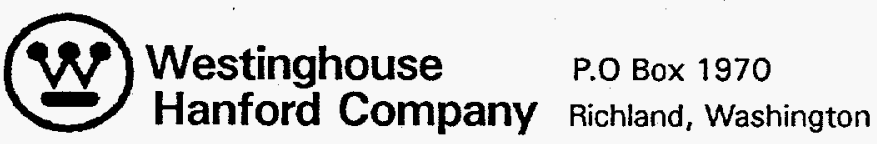

Hanford Operations and Engineering Contractor for the

U.S. Department of Energy under Contract DE-AC06-87RL10930

Copyright License By acceptance of this article, the publisher and/or recipient acknowledges the

U.S. Government's right to retain a nonexclusive, royalty-free license in and to any copyright covering this paper. 
MATERIAL SELECTION FOR MULTI -FUNCTION WASTE TANK FACILITY TANKS

A.P. Larrick. L.D. Blackburn. W.F. Brehm. W.C. Carlos and J.P. Hauptmann Westinghouse Hanford Company

P:0. Box 1970

Richland. WA 99352

M.J. Danielson and R.E. Westerman

Pacific Northwest Laboratory

P.0. Box 999

Richland, WA 99352

J.R. Divine

ChemMet, Ltd. . P.C.

P.0. Box 4068

West Richland. WA 99352

\author{
G.M. Foster \\ ICF Kaiser Engineers \\ P. 0. Box 888 \\ Richland. WA 99352
}

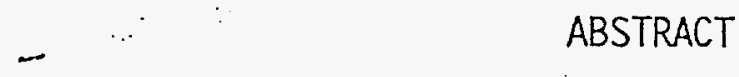

This paper briefly sumarizes the history of the materials selection for the U.S. Department of Energy's high-level waste carbon steel storage tanks. It also provides an evaluation of the materials for the construction of new tanks at the Multi-Function Waste Tank Facility.

The evaluation included a materials matrix that sumarized the critical design, fabrication. construction, and corrosion resistance requirements; assessed. each requirement: and cataloged the advantages and disadvantages of each material. This evaluation is based on the mission of the Multi-Function Waste Tank Facility. 
On the basis of the compositions of the wastes stored in Hanford waste tanks. it is recommended that tanks for the Multi-Function Waste Tank Facility be constructed of ASME SA 516. Grade 70, carbon steel.

Keywords: materials, selection, carbon steel tanks, fabrication, corrosion resistance, high-level radioactive waste

\section{GLOSSARY}

\begin{tabular}{|c|c|}
\hline ASME & American Society of Mechanical Engineers \\
\hline ASTM & American Society for Testing and Materials \\
\hline AWS & American Welding Society \\
\hline B\&PV Code & ASME Boiler \& Pressure Vessel Code \\
\hline Certificate Holder & $\begin{array}{l}\text { The Certificate Holder has the authorization from the ASME } \\
\text { which indicates the responsibilities assumed by the } \\
\text { Certificate Holder. e.g. design. construction, and other } \\
\text { services. The responsibilities and duties of the Certificate } \\
\text { Holder are } 1 \text { isted in the ASME B\&PV Code. Section III. Division } \\
1 \text { and 2. Article NCA-3000. "Responsibilities and Duties." }\end{array}$ \\
\hline CS & Carbon steel \\
\hline DOE & U.S. Department of Energy \\
\hline dpa & Displacements per atom \\
\hline DST & Double-shell tank \\
\hline FDC & Functional design criteria \\
\hline Hanford & A DOE site at Richland, Washington \\
\hline$H A Z$ & Heat-affected zone (of a weld) \\
\hline HWVP & Hanford Waste Vitrification Project \\
\hline kip & Kilopound $=1.000 \mathrm{lb}$ \\
\hline Liner & $\begin{array}{l}\text { 3/8-in.-thick }(0.95 \mathrm{~cm}) \text { internal CS tank structure that } \\
\text { extends across the tank basemat of a single-shell tank and up } \\
\text { the cylindrical sides: its purpose is to contain the waste }{ }^{44}\end{array}$ \\
\hline LST & Lowest service temperature \\
\hline MWTF & Multi-Function Waste Tank Facility \\
\hline & Nil-ductility transition temperature \\
\hline Product anaiysis & $\begin{array}{l}\text { As stated in ASME SA } 20 \text {, a chemical analysis shall be made of } \\
\text { each plate as rolled. The specimens for analysis shall be } \\
\text { taken adjacent to or from a broken tension-test specimen. The } \\
\text { chemical composition thus determined, as to elements required } \\
\text { or restricted, shall conform to the product analysis } \\
\text { requirements specified in the applicable specification. } \\
\text { Post-weld heat treatment }\end{array}$ \\
\hline
\end{tabular}


$\mathrm{S}$

$\mathrm{S}_{\mathrm{m}}$.

SRS

SS

SST.

Stamped

Type III

UT

UTS $\left(\sigma_{u}\right)$

WHC

WSRC

WVS

WVNS

YS $\left(\sigma_{y}\right)$
Maximum a 7lowable stress at temperature

Stress-corrosion cracking

Design stress intensity at temperature

Savannah River Site - a DOE site at Aiken. South Carolina Stainless steel

Single-shell tank.

The ASME stamp applied by the pressure vessel manufacturer to the pressure vessel and is defined in the 1992 ASME Boiler \& Pressure Vessel Code. Section III, Division 1 and 2. Article NCA-8000. "Certificates of Authorization. Nameplates, Code Symbol Stamping, and Data Reports."

Savannah River Site designation for DSTS

Ultrasonic testing

Ultimate tensile strength

Westinghouse Hanford Company

Westinghiouse Savannah River Company

West Valley Site - a DOE site at West Valley. New York West Valley Nuclear Services. Inc.

Yield strength

\section{INTRODUCTION}

New storage tanks are to be constructed at the Multi-Function Waste Tank Facility (MWTF) at the U.S. Department of Energy's (DOE) Hanford Site near Richland, Washington. The mission of the new MWTF tanks is interim storing of waste, a mission similar to that of the existing 28 double-shell (DST) high-level waste tanks. Because all waste to be stored in MWTF tanks will have previously been stored in or passed through CS DSTs, or will be sent to other.DSTs, the waste composition will need to meet the Hanford waste tank corrosion specification?. This report describes the evaluation of several carbon steel (CS) plate materials materials of the type that have already shown successful application in storage of similar high-level radioactive waste at the Hanford Site and at the Savannah River Site (SRS).

These steels include several ASME grades of carbon-manganese-silicon and carbon-silicon steel plates intended for fusion-welded pressure vessels (tanks). They were evaluated to determine their suitability for construction and storage of high-level radioactive wastes. The evaluation was aided by a materials matrix (Table 1) summarizing the criteria for material design requirements. susceptibility to corrosion. and strength properties of the candidate carbon steels. This evaluation is supported by the MWTF tank failure mode analysis ${ }^{3}$. 
BACKGROUND

The history of large, radioactive-waste storage tanks begins at the Hanford Site and later extends to the West Valley Site (WVS), and SRS sites. The welded storage tanks at Hanford date back to World War II. It is believed that these were state of the art at the time of their construction. The large CS radioactive-waste storage tanks are discussed briefly below:

An aspect of historical development that affects the SA 516 and SA 537 CS plate used in these tanks is the significant improvement in steel making over the last 24 years. The SA 516 CS plate produced today is not the same as that produced in 1970. Today's SA 516 CS plate is much "cleaner" because it is produced by electric-arc melting. Twenty years ago, the steel was produced from pig iron in open-hearth furnaces or by the "Bessemer Process." Today. CS plate is made. not from pig iron, but. from old steel. principally from old cars and railroad rails. Recycled steel is much purer than pig iron. Furthermore, the electric-arc melter process is more accurate than the open-hearth process. Because the electric-arc melter can be tilted. slags can be removed quickly, and oxidizable elements. such as chromium and manganese, can be recovered more efficientiy. Slag control minimizes ladle deoxidation: thus the steel has fewer sulfide and oxide inclusions. Control of the elemental composition by means of metal additives is now very precise. The melt can be vacuum-degassed, argon-blown. and magnetically mixed. Because the plate is cleaner, it is less susceptible to hydrogen degradation. Table 1 summarizes the DST tank carbon steels, their installation dates. and locations.

Hanford Site, Richland, Washington

In 1943, construction of large single shell storage-tank (SST) liners followed the American Water Works Association practices ${ }^{43}$ and were built from ASTM A7 CS 4 . After 1947. SST liners were made of ASTM A 283, A 285, and ASTM A 201 $\mathrm{CS}^{4}$. The DST primary tanks built in 1970 were constructed of ASTM A 515 CS; after 1977. such tanks were built of ASTM A 516, and after 1978. of ASTM A 537 CS $^{4}$. Al1 of the Hanford DST primary tanks were stress relieved (post-weld heat treated [PWHT] $)^{4}$. A7l 28 Hanford DSTs have alkal ine waste stored in them: none have leaked. A complete list of the Hanford tanks and materials of construction appears in Table 1.

Savannah Riverer Site, Aiken, South Carolina

Savannah River (SRS) began building large ASME-designed storage tanks in 1952 using ASTM A 285 Firebox Quality CS ${ }^{6}$. Between 1967 and 1974. the SRS site fabricated DST's from ASTM A 516 normalized CS. Tanks constructed there since 1974 are of ASTM A 537. All of the SRS Type III tanks have been. PWHT' ${ }^{6}$. The SRS Type III tanks store alkaline waste and have not leaked. The SRS DSTs are listed in Table 1.

West Valley, New York

West Valley has two 1.000.000-gal ASME-designed storage tanks that were built in. 1964 from ASTM A201 PWHT CS: They. store alkaline waste and have not leaked". The WVS tanks are listed in Table 1. 


\section{MATERIAL SELECTION}

The CS plate considered for selection for the MWTF tanks included the two most recent specifications. ASTM A 516 and A 537. that were successfully used at Hanford and SRS to fabricate tanks for waste storage, 4 . Because of the desire to maximize the strength of the tank materia7. ASME SA 516. Grades 60 and 65. were eliminated from consideration in preference to SA 516. Grade 70, and ASME SA 5.37. Class 1.

The intention is to have the tanks code stamped: therefore, it is important to use the SA designation (ASME) rather than the A designation (ASTM). The mechanical properties and chemical compositions of the two materials are quite similar. Both of these CS plate material specifications were evaluated to determine whether they met minimum MWTF project ASME Section III tank design and corrosion-resistance requirements. To meet the MWTF project technical requirements, a set of acceptance criteria was developed that focused on critical material propertiès, i.e., constructability. weldability, availability, corrosion, and degradation resistance. The characteristics of each plate material being considered then were determined and measured against the acceptance criteria.

Composition and Material Properties

Table 2 shows the compositions of the alloys considered for the MiNTF tanks. Design, material, and corrosion-resistance properties are summarized in a matrix in Table 3 and discussed in the sections below.

ASME Boiler \& Pressure Vessel Code Section III Acceptance.

- Considerations

Although not nuclear power plant components, the primary MWTF tank will be designed to 1992 Edition with the 1993 Addenda of ASME Section III. Division 1. Subsection NC. "Rules for Construction of Nuclear Power Plant Components. Class 2 Components"8. Article NC-2000. Subarticle NC-2120. "Pressure Retaining Material." and NC-2121, titled "Permitted Material Specifications." states the following: "(a) Pressure retaining material shall conform to the requirements of one of the specifications for materials listed in Table 1A. Section II. Part D. Subpart I, and to $a l l$ the requirements of this Article which apply to the product form in which the material is used." Table 1A Tists SA 516. Grades 55, 60, 65, and 70, and SA 537. Class 1.

The ASME Boiler \& Pressure Vessel Code (B\&PV). Section II. Materials. Part A. "Ferrous Material Specifications, 1992 Edition. July 1, 1992." iists SA 516. "Specification for Pressure Vessel Plates. Carbon Steei. for Moderate- and LowerTemperature Service." and SA 537. "Specification for Pressure Vessel Plates. Heat Treated. Carbon-Manganese-Silicon Steel"?

'ASTM and ASME specifications are identical. The ASME Code requires materials to be ordered to an SA specification. 
- Evaluation

The CS materials being considered. ASME SA 516. Grade 70, and SA 537. ClasS 1, are all ASME Section III acceptable.

\section{Availability.}

- Considerations

The tanks are to be fabricated from-CS plates (Figure 1). The tank fabricator will try to maximize the sizes of the plates. to minimize the number of welds..-The larger the plate sizes, the less weld length required.

- Evaluation

The CS materials being considered. SA 516 and SA 537, are available in $*$ -

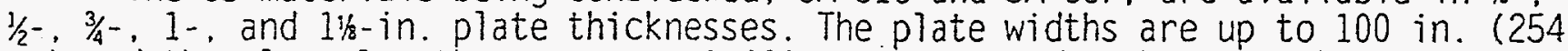
$\mathrm{cm})$ and the plate lengths are up to 1.080 in $(2743 \mathrm{~cm})$ : Both materials can be obtained in the normalized condition.

\section{Constructability.}

- Considerations

The plates must be formed in the upper and lower knuckle areas and the head. These plates must also be rolled to form the shape of the tank. Some of this work will be performed in a fabrication shop. Most of the tank is field welded.

- Evaluation

The CS materials SA 516. Grade 70, and SA 537. Class 1, are considered to have equal "relative difficulty to fabricate". Of the world's tanks, $85 \%$ are made of SA $516^{10}$.

\section{Material Strengths.}

- Considerations

The CS plates must have a strength adequate to support the applied loads and contents of the tank. The tank designers want to maximize the strength of the steel if its other-properties can be maintained in a suitable range at the same time.

- Evaluation

Both carbon steels ASME SA 516. Grade 70, and SA 537. Class 1, have a minimum ultimate tensile strength (UTS) level of $70 \mathrm{kip} / \mathrm{in}^{2}$ ( $483 \mathrm{MPa}$ ). For some design purposes the yield strength (YS) is used. The minimum yield strength at ambient temperature of SA 516. Grade 70 . is $38.0 \mathrm{kip} / \mathrm{in}^{2}(262 \mathrm{MPa}$ ) and the yield strength of SA 537. Class .1. is $50.0 \mathrm{kip} / \mathrm{in}^{2}$ (345 MPa). Both materials have acceptable yield strength levels, even though that of SA 537. Class 1, is higher. At the design temperature of the MWTF tanks $\left(250^{\circ} \mathrm{F}\left[121^{\circ} \mathrm{C}\right]\right)$. $S$ and $S_{\mathrm{m}}$ are nearly equal for the two steels. Since the design temperature strength is nearly equal. selection between the two steels is not influenced significantly by this parameter. 
Weldability. The plates will be joined by welding. The joining of CS plates by arc welding is responsible for the modern storage tank. Before the advent of welding. tanks were riveted together. Widespread use of arc welding to join CS plates began during World War II. The tank fabricator will maximize the fraction of automatic welding to minimize construction time and labor costs. Next to the forming of the plate steel, welding is the largest single fabrication operation in the construction of the tanks.

\section{- Considerations}

- Weld Metal. The arc welds produced with bare electrodes in the late 1920's and early 1930's exhibited poor mechanical properties. The advent of flux- and gas-covered electrodes in the 1940's and $1950^{\prime} \mathrm{s}$ revolutionized the welding industry. Today's electrodes are designed to match base metal chemistry and mechanical properties: improve the deposition rate; and compensate for the types of current, joint designs, and positions of welding. The electrodes used in construction of the MWTF tanks will be primarily spooled continuous wire or tubular electrodes to support the automatic welding processes.

- Welding Processes. The first all-welded structures were built in America in the 1940 's. The later addition of flux to the welding electrode stabilized the arc and produced stronger, defect-free welds. Gasses are now used solely or in combination with fluxes to protect the molten weld metal from the atmosphere. High-production semi-automatic and automatic welding processes (submerged arc welding. gas metal arc welding. flux-cored arc welding) will be used in the MWTF tank construction. The quality of the welds has improved proportionalily to the advancement of the welding processes.

- Welding Examination. The welding examination process has also improved over the years. For example, the radiographic film used today is much more sensitive than that used on the original Hanford tanks in the $1940^{\circ} \mathrm{s}$. Ultrasonic, magneticparticle, dye-penetrant, acoustic-emission. leak-detection (vacuum box), and eddycurrent weld inspection, all nondestructive examination techniques, were not available or were seldom used in the $1940^{\prime}$ 's. but are routinely used today for inspecting welds. The waste tanks at Hanford have always had $100 \%$ radiography of the welds.

\section{- Evaluation}

The pressure vessel plate materials SA 516, Grade 70, and SA 537, Class 1. are considered readily weldable with the processes normally employed in tank construction. Submerged arc welding. flux-cored arc welding, and shielded metal arc welding are the most common welding processes used. For welding procedure qualification purposes, both SA 516. Grade 70. and SA 537. ClasS 1, are listed in ASME Section IX as a P-No. 1. Group No. 2, material. The group number classifies the metal for the purpose of procedure qualification where notch-toughness requirements are specified". Because the tanks are PWHT (stress relieved), the welding procedures must be qualified in the PWHT condition. American Welding Society (AWS) classified filler metals are available in the $70 \mathrm{kip} / \mathrm{in}^{2}$ range for the various welding processes. The welding position, i.e. flat, vertical. horizontal. or overhead, will dictate the selection of welding process, filler metal, and number of weid passes that are required for a given thickness of material. A $50^{\circ} \mathrm{F}\left(9.9^{\circ} \mathrm{C}\right)$ minimum preheat temperature is suggested. A $200^{\circ} \mathrm{F}(93$ 
$\left.{ }^{\circ} \mathrm{C}\right)$ preheat is recommended when the ambient temperature is below $32{ }^{\circ} \mathrm{F}\left(0{ }^{\circ} \mathrm{C}\right)$ or the base metal thickness is greater than 1 -in $(2.54 \mathrm{~cm})$. The low carbon chemical content of SA 516. Grade 70. suggests that weld cracking should not be a problem.

Post-Weld Heat Treatment.

- Considerations

Post-weld heat treatment (PWHT) (stress relieving) of the CS was determined to be required at SRS and Hanford to prevent nitrate-assisted stress-corrosion cracking (SCC) of the CS storage tanks ${ }^{6,12}$.

PWHT of the MWTF primary storage tanks is not required by code requirements. as plate thicknesses are below the minimum required by the ASME B\&PV Code for PWHT. Nevertheless, the ASME B\&PV Code PWHT criteria for stamped vessels will be used because of the need to prevent SCC.

- Evaluation

Two different approaches to PWHT for the MWTF tanks have been advanced. One is the so-called "lift-and-set" method where PWHT is done remotely from the support pad and items are lifted and placed on the support pad by crane.

The second approach is to PWHT "in-place." i.e., on the support pad. Each approach can be accomplished in several different ways. ICF Kaiser Hanford Company (ICF KH) has identified an "in-place" PWHT method as the best method and as a baseline for evaluating other methods. The concrete support pad will be placed in two different pours. The first pour will be made before PWHT to a 33- to 35-ft $(10.08-10.67 \mathrm{~m})$ radius. The second will be made after PWHT and extend out to a radius of approximately $37.5 \mathrm{ft}(11.43 \mathrm{~m})$. During construction, the weight of the walls, head, and lower knuckles wili be supported by appropriately placed "A" frames mounted on trunnions.

This approach will allow the floor plates to "float" on that portion of the support pad in place during the PWHT cycle, thus reducing the possibility for local warpage of the floor plates. Pouring the last 4 to $5 \mathrm{ft}(1.2-1.5 \mathrm{~m})$ of the support pad after the PWHT cycle will place a ring of normal-strength concrete around the pad to carry. loads from the tank wall and dome.

\section{Brittle Fracture.}

\section{- Considerations}

Brittle fracture has been responsible for some of the most disastrous storage tank failures in tank history.3. The two candidate steels for MWTF tanks. SA 516. Grade 70 , and SA 537 . Class 1, exhibit a change in fracture mode from ductile to brittle at low temperatures.

At Savannah River (SRS) in about 1975, there was concern about the possibility of brittle fast fracture. Brittle fast fracture is a phenomenon that occurs when steels below their nil-ductility transition temperature (NDT) are stressed and have a small flaw of critical size and geometry. The SRS nuclear waste storage tanks. Types I and II and half of the Type IV were built of 
ASTM A 285-B steel. Data for this steel show that in less than $1 \%$ of the heats produced. the NDT was as high as $20^{\circ} \mathrm{C}\left(68^{\circ} \mathrm{F}\right)^{6}$. A temperature of $21^{\circ} \mathrm{C}\left(70^{\circ} \mathrm{F}\right.$ ) was chosen for SRS standards as the lowest operating temperature for ASTM A 285-B tanks.

Type III tanks were built of ASTM A 516. Grade 70; A 516. Grade 70 normalized; and finally A 537. Class 1. Two reasons for the changes in grades of steel were offered. The first was that earily SCC studies had shown that resistance to SCC increased from ASTM A 285-B to A 516. Grade 70, and to A 537. Class $1^{14}$. SCC had been the main problem with SRS waste tanks at the time. The second reason was the-concern over NDT. It was known that normalized steel had much better fracture toughness: Normalization lowered the NDT by about $30^{\circ} \mathrm{C}\left(54^{\circ} \mathrm{F}\right)$. The result was a reduction of NDT to a level no longer of any concern for brittle fast fracture in SRS waste tanks. For these two reasons. more resistance to SCC and reduction in the NDT, the change was made from ASTM A 285-B to 516. Grade 70, for Type III tanks, then to 516. Grade 70 normalized. To reduce residual stresses. PWHT was also instituted on Type III tanks.

Concern was expressed that 516. Grade 70 normalized, might be shipped to SRS in the non-normalized state by mill or jobber error. as normalization is a special treatment and must be requested for this alloy. This possibility of error. coupled with resistance to SCC. led to the change from ASTM A 516. Grade 70 normalized, to ASTM A 537. Class 1. The latter alloy can only be supplied in the normalized condition: it has essentially the same materials properties as ASTM A 516. Grade 70 normalized. and has stricter specifications on the amounts of impurities.

- During Construction. Brittle fracture can occur during construction if the tank sections, plates, domes, or bottoms are lifted during fabrication on a cold day. Construction activities should consider brittle fracture prevention; lifting must be restricted during very. cold weather:

- During the 50-Year Service Life. The design code for the tanks (ASME B\&PV Code. Section III. Subsection NC) provides protection against brittle fracture by imposing rules ensuring that materials of construction exhibit an adequate toughness.

\section{- Evaluation}

The selection of ferritic steel for the tanks means that consideration must be given to protection against brittle fracture, both during service and during construction.

- During the 50-Year Service Life. The design code for the tanks is the ASME B\&PV Code. Section III. Subsection. NC. This code provides protection against brittle fracture by imposing rules that ensure that materials of construction exhibit a ductile failure mode at the lowest service temperature (LST). work in progress to develop a design specification for the tanks has identified a LST of $+40^{\circ} \mathrm{F}\left(4.4^{\circ} \mathrm{C}\right)$. Either SA 516. Grade 70, or SA 537. Class 1. wil1 meet the design code requirements without special provisions in the procurement ordering data specifying NDT temperature or impact tests. If subsequent work leads to a lower value of LST in the final design specification. it would be expected that either steel could satisfy code requirements by including a specific NDT temperature limit in the ordering data. 
- During Construction. Work in progress to develop a design specification for the tanks has identified a requirement that the contractor shall establish controls to prevent brittle fracture during field construction. A general review of expected conditions during construction. including applied and residual stresses. loading rate. and sources and sizes of flaws. led to the judgement that the contractor should be able to preclude fracture during construction with either of the candidate steels.

\section{Fatique Properties.}

- Considerations

Appendix XIV of the ASME Code, Section III. Division 1, provides rules for the fatigue analysis for Class 2 vessels designed in accordance with NC-3200. However, the rules for determining whether or not a fatigue analysis is required are given in NC-3219.

- Evaluation

The maximum temperature of the liquid waste in the tank will be about $200{ }^{\circ} \mathrm{F}$ $\left(93^{\circ} \mathrm{C}\right)$ : the tanks will undergo a total of $200 \mathrm{fill}$ and drain cycles during their design life of 50 years. Assuming one temperature cycle per fill? the number of temperature cycles is also 200. Conservatively, the factor to be applied for calculating the effective number of cycles is assumed equal to the number of changes in temperature between two adjacent points. Such a large temperature difference is not expected as the operation of the mixer pumps will keep the temperature of the liquid nearly uniform. This conservative factor yields 400 as the effective number of changes in the metal temperature between two adjacent points. Therefore, the total number of cycles is 600 . As this number is smaller than the 1.000 cycles allowed by the Code, no fatigue analysis for the tank is required provided the material selected for the tank does not have a specified minimum tensile strength greater than $80 \mathrm{kip} / \mathrm{in}^{2}$. All of the materials being considered have a minimum tensile strength below $80 \mathrm{kip} / \mathrm{in}^{2} .{ }^{15}$

Condition A of NC-3219.2 is used here to demonstrate that no fatique analysis is required for the primary tanks. Thus. neither SA 516. Grade 70, nor SA 537 wi 11 be affected by fatigue during the 50 -year design service 7 ife $e^{15}$.

\section{Effects of Radiation.}

- Consĩderations

The CS waste-storage tanks at Hanford and at other DOE sites are exposed to high levels of alpha. beta, or gamma radiation. but little neutron radiation.

Savannah River (SRS) tanks and wastes are similar to those at Hanford. Although the radiation levels in the MWTF tanks are expected to be lower than the levels used in the SRS study ${ }^{16}$, the SRS radiation levels will be used in this study because they are documented.

Large high-level radioactive CS storage tanks have been evaluated by Caskey ${ }^{17}$. His findings will be cited. 


\section{- Evaluation}

The waste stored in the SRS tanks (like that stored at Hanford) contains radionuclides that decay mostly with the release of alpha, beta, or gamma radiation and. to a lesser extent. spontaneous neutrons. These products of radioactive decay interact with solid materials and may displace atoms from their normal sites, thus generating vacancies and interstitiais that alter the mechanical properties of the steel $^{17}$.

- Alpha Radiation. Displacement damage from alpha radiation (energies of 4.0 to $5: 8 \mathrm{MeV}$ ) would be limited to a depth of 5 to $15 \mu \mathrm{m}$ into the steel surface that faces the waste ${ }^{17}$.

- Beta Radiation. Any displacement damage from beta emission would be limited to a depth of less than one millimeter and can result only from beta emissions with an energy greater than approximately $0.5 \mathrm{MeV}$ that originate within 1 $\mathrm{cm}$ of the tank wall] ${ }^{17}$.

- Gamma Radiation. Hanford tanks are exposed primarily to gamma radiation at levels usually less than 1,000 R/hr.

- General Corrosion - Corrosion rates of A $216 \mathrm{CS}$ specimens at $150{ }^{\circ} \mathrm{C}$ $\left(302{ }^{\circ} \mathrm{F}\right.$ ) and a radiation level of $2.000 \mathrm{R} / \mathrm{hr}\left({ }^{60} \mathrm{CO}\right)$ showed no significant increase in general corrosion above those rates obtained under non-radiation conditions after three months of exposure in concentrated chloride brine ${ }^{18}$.

- SCC - After seven months of exposure both to radiation and simulated waste, there is no evidence that American Iron and Steel Institute (AISI) 1025 CS is susceptible to SCC ${ }^{18}$. AISI 1025 is similar to. SA 516 and SA 537 CS.

- o Neutron Radiation - The maximum displacement damage from spontaneous neutron fission is estimated to be less than 4.0E-11 dpa ${ }^{17}$.

- Nil Ductility Temperature, Ductility, and Strength - The major effects of displacement damage on carbon steels are an increase in the temperature that separates low-temperature brittle fracture from ductile failure at higher temperatures: a lowering of the energy of ductile failure, and an increase in the strength. The transition from ductile to brittle behavior is indicated by NDT. The estimated displacement damage caused by gamma radiation from high-level waste is below the lower limit. $<1.0 \mathrm{E}-5 \mathrm{dpa}$ (displacements per atom), of the experimental data for effects of radiation on the NDT of $\mathrm{CS}^{17}$. An estimate of the effect of the displacement damage on the NDT of the waste tank steel is an increase of about $6.4^{\circ} \mathrm{F}\left(3.6^{\circ} \mathrm{C}\right)^{77}$.

Based on the findings of Caskey ${ }^{17}$ and Carlos ${ }^{19}$ and the successful operation of 53 DOE CS waste tanks, none which have been identified as having been affected by radiation. as well as the evidence provided by hundreds of CS nuclear reactor vessels, which operate at much higher levels of radiation. the conclusion is that neither SA 516. Grade 70, nor SA 537 CS will be affected by radiation during the 50 -year design life of the tanks. 


\section{Corrosion Properties}

Several methods are available to rate or compare the corrosion resistance of carbion steels. The discussion below considers the corrosion or material degradation modes affecting the 50-year design life of the MWTF tanks. Each type of corrosion will be evaluated for its effects.

\section{General Corrosion.}

- Considerations

After construction, the high-level radioactive waste must be compatible with the CS plates from which the MWTF tanks are constructed. General or uniform corrosion of metal occurs in the liquid waste. The determination of whether general corrosion will be less than 1 mil/year $(0.0254 \mathrm{~mm} / \mathrm{y})$ is evaluated.

- Evaluation.

General corrosion of the CS in Hanford wastes has been studied extensively and can be controlled to remain below the $1 \mathrm{mill} /$ year $(0.0254 \mathrm{~mm} / \mathrm{y})$ general corrosion acceptance criterion stated in the functional design criteria. The waste in the MWTF tanks must be inhibited per the Hanford Waste Tank Corrosion Specification ${ }^{2}$.

\section{Stress-Corrosion Cracking.}

- Considerations

SCC is caused by the simultaneous presence of a sensitive material. tensile stress, and a specific corrosion medium ${ }^{21}$. SCC of CS can occur in the presence of caustic and in nitrate solutions. Failure of some SRS SSTS was determined to have been caused by nitrate-assisted $S C C^{6,22}$ A similar conclusion has been reached about the failures of Haiford SSTS $12,23,24,25,46$. SCC prevention methods have been developed and must be implemented on the MWTF tanks to ensure a 50 -year design 7 ife.

- Materials. Both candidate MWTF tank materials are susceptible to nitrate and hydroxide SCC.

- Environments. The MWTF primary tanks will contain both nitrate solutions and hydroxide solutions.

- Stresses. Without PWHT, the as-fabricated MWTF primary tank, because of external loads and residual stress from welding. especially in the knuckle area, will experience stress levels that can produce SCC.

- Evaluation

There is substantial evidence that early SRS and perhaps Hanford CS SSTS failed by nitrate-assisted SCC. In contrast since 1968. SRS. Hanford, and WVS CS DSTs have stored nitrate wastes successful7y $4,5,6,7$. 
For SCC to occur. three conditions must come into play simultaneously: SCCproducing environments, SCC-sensitive materials, and stresses. Removing any one of these three can control SCC. The Hanford tank environment comprises the waste, the carbon steel tank material. and the stresses, mainly residual stresses from welding. The loading stresses, by design, are low except during a seismic event. The most highly stressed area of the tank is the knuckle section. the section joining the tank walls to the tank bottom.

- Tank Stresses. Tanks are fabricated from CS plates joined together by welding. Residual stresses are reduced after fabrication by PWHT as described earlier.

- Plate Material. Tank plate materials have improved significantly since 1944 and even more over the last 20 years because of modern plate mill melting practices and advances in plate metallurgy. The MWTF tanks will be made from CS plates produced in modern plate mills with advanced metallurgical and process technology far better than that used in the past. Nevertheless, materials being considered are susceptible to nitrate SCC: therefore. SCC. control must by reducing stresses or altering the environment.

- Tank Environment. Because of the SST leaks. SRS did a "post mortem" on Tank 16 and performed several corrosion tests to develop a method to control nitrate-assisted $\mathrm{SCC}^{14}$. Zapp ${ }^{26}$ continued this work into higher temperatures. Hanford adapted most of this SCC control program (Kirch 1984) and confirmed its validity by corrosion tests performed by Divine (1985). This program imposes sodium nitrite and sodium hydroxide inhibitor additions to the wastes at concentrations that vary depending on the nitrate concentration.

With modern materials. PWHT. and chemical inhibiting. SCC can be prevented in the MWTF tanks.

\section{Pitting Corrosion.}

- Considerations

Pitting corrosion can occur in several different locations or environments. called zones, in the MWTF tank (see Figure 4). Corrosion prevention or control in each zone or environment is addressed separately.

- Vapor Zone Corrosion. When the dew point temperature of the air within the tank exceeds the temperature of the dome steel of the tank. water vapor will condense on the dome of the tank. The water (condensate) will either eventually run down the sides of the tank or drip into the waste. Pitting occurs within corrosion cells which form where the condensate collects in drops and where they run down the sides of the tanks. Vapor space corrosion can be severe. Historical corrosion tests at several DOE sites concerning waste tanks indicate that the greatest corrosion and the highest corrosion rates occur in the vapor zone in the
tanks $18,27,28,29,30,45$.

- Interface Zone Corrosion. It has been suggested that pitting corrosion in the interface zone is also a serious corrosion form ${ }^{31}$. Interface corrosion may take place on the tank walls in the area where the liquid zone meets the vapor zone. in the meniscus ${ }^{27}$. At least two mechanisms are contributing to this type of corrosion: 
dilution of the bulk waste solution by condensate and hydroxide depletion by carbon. dioxide absorption in the meniscus area.

- Dilution of the Meniscus Solution by Condensate - Closed-circuit video of the interiors of some SSTS. DSTs and other underground storage tanks show condensate collecting on the domes of the tanks and running down the tank walls to the waste/air interface. The condensate. when it flows into the meniscus, will dilute the meniscus sollution lowering its hydroxide level. The hydroxide in the solution is the corrosion inhibiting agent, and diluting it allows corrosion to take place on the tank wall (called interface corrosion).

- Carbon Dioxide Absorption in the Meniscus Solution - Absorption of atmospheric carbon dioxide has been experimentally confirmed to cause depletion of free hydroxide in the dilute alkaline solutions stored in SRS waste tanks. Absorption of the carbon dioxide will continue until the bulk solution in the meniscus is at a pH equilibrium of 9.5. A waste sample from a tank at SRS. after twenty months of storage. confirmed the prediction and was found to have a pH of $9.5^{32,33}$. Laboratory data at SRS suggest that this situation could contribute to pitting of the CS in the meniscus ${ }^{26}$.

- Evaluation

Pitting corrosion also can be prevented or controlled. Each potential location of corrosion will have to be controlled differently because each will occur in a different environment.

- Vapor Zone Corrosion. Vapor zone pitting corrosion can be addressed by preventing its occurrence or by adding a corrosion allowance to the ASME minimum wall thickness. The two carbon steels considered for tank materials exhibit similar vapor zone corrosion characteristics, so that the material selection was independent of this criterion.

The MWTF project will address vapor zone corrosion by adding a 1 mpy $(0.0254$ $\mathrm{mm} / \mathrm{y}$ ) general corrosion allowance and injecting gaseous ammonia into the inlet air. An additional corrosion allowance for pitting was judged impractical since the measured rates. indicated an allowance of 2 inches $(5.08 \mathrm{~cm})$ would be required. The injection of ammonia, at a very low level (ppm). would occur only when vapor zone corrosion is detected by the vapor zone corrosion monitoring probes and/or when the tank's relative humidity (dew point control) is above $\% 50$. The subject of MWTF tank vapor zone corrosion is specifically addressed by Larrick ${ }^{34}$.

- Liquid Zone Corrosion. In the liquid zone, nitrate wastes properly inhibited with nitrites or hydroxides per the Hanford waste tank corrosion technical specification ${ }^{2}$ will control the pitting corrosion of the wetted (immersed) sections of the tanks. i.e., those portions of the tank bottom and the walls in contact with the waste.

Extensive testing of the corrosion effects of high-level radioactive wastes on CS at SRS led to the development of chemistry ranges within which waste should be maintained to minimize corrosion ${ }^{14}$. SRS also developed inhibiting programs to prevent and/or control corrosion within these ranges ${ }^{14}$. These inhibiting programs have been adapted at the Hanford Site $e^{2}$ and confirmed as a safe operating practice ${ }^{20}$. 
- Interface Zone Corrosion. The MWTF project will address tank interface zone corrosion by preventing the condensate collecting on the tank dome from running down the wall of the tank and diluting the meniscus hydroxides ions in the interface zone by installing a drip ring on and near the outer diameter of the dome. The condensate will then run down the dome until it hits the drip ring where it will drip back into the waste and not end up in the meniscus area where it can increase corrosion. Furthermore, the mixing pumps will intermittently operate in the MWTF tanks. This pump action will replenish the hydroxide ion in the meniscus area. preventing severe depletion of the hydroxide ion in the interface zone.. Both these solutions are independent of material selection. The subject of MWTF tank interface zone corrosion is specifically addressed by Larrick ${ }^{34}$.

\section{Crevice Corrosion.}

- Considerations

Crevice corrösion may occur in any crevice or crevice-7ike features due to deposits and weld fractures on the internal surfaces of the MWTF tank.

- Evaluation

Butt welding (joining) of the plates will eliminate most crevices. No fillet welds are allowed inside the tanks. Nevertheless, conditions such as those described below will lead to crevices on the MWTF tank surfaces during their 50year service life.

- Precipitates from the waste. similar to the crust in tank TK-241-SY101. will float on the waste and create a "bathtub ring" on the tank wall at the interface of the waste and the vapor zone. These coatings prevent access of oxygen under the coating and act os crevices.

- Objects may be dropped into a tank. The space between the object and the bottom of the tank becomes a crevice.

- The crown edges of welds sometimes act as crevices. There are thousands of linear feet of welds in the MWTF tank and the weld crowns will not be ground flat to the inner. surface of the tank plate. The point at which a vertical weld meets a horizontal weld also can become a crevice.

The prevention of crevice corrosion will be addressed administratively and during the flushing and cleaning of the tank between service cycles.

- Objects must not be dropped or allowed to fall into the tank. When the tank is empty, any objects on the bottom must be removed.

- Precipitates or coating on the side of the tank ("bathtub ring") should be removed when the tank is emptied, flushed, and cleaned. At Idaho Fal1s, the in-tank light-duty utility arm (LDUA) has a "water blast" cleaning attachment. which could be used to remove the "bathtub ring" in the MWTF tanks. Hanford plans to purchase two in-tank LDUAs. 
Like pitting. crevices in the liquid waste zone can be prevented or controlled by proper inhibition with nitrites or hydroxides per the Hanford waste tank corrosion technical specification ${ }^{2}$ : such inhibitors will control the pitting corrosion of the wetted (immersed) sections of the tanks. i.e.. the tank bottom and the walls in contact with the waste:

\section{Erosion Corrosion.}

\section{- Considerations}

A-mixing pump will be installed in each MWTF tank to keep waste solids in suspension (see figure 2). Because the pump will eject waste at high velocities toward the walls and bottom of the tank. concern has been expressed that the walls and bottom will experience excessive wear during their service lifetime.

- Evaluation

Divine 35 has assessed erosion-corrosion effects on CS tanks. Factoring in the effects of the impact of the waste on the CS bottom plates caused by the mixing. pumps resulted in an erosion-corrosion allowance of $3 \mathrm{mil} / \mathrm{year}(0.0762 \mathrm{~mm} / \mathrm{y})$. Divine recommends adding an erosion-corrosion allowance of 3 mil/year $x 50$ years $(0.150$ in. $)(0.38 \mathrm{~cm})$ of material to the bottom of the tank. This erosion-corrosion allowance is in addition to the 1 mil/year general corrosion allowance. Thus, an erosion-corrosion allowance of $3 \mathrm{mil} /$ year plus a $1 \mathrm{mil} /$ year general corrosion allowance would equal 4 mil/year $\times 50$ years. or $0.200 \mathrm{in}$. $(0.5 \mathrm{~cm})$. to be added to the ASME minimum wall thickness calculations. The walls of the tank require no erosion-corrosion allowance.

Based on the erosion-corrosion allowance recommended for addition to the ASME-designed minimum wall thickness for the CS botton plates, the conclusion is that erosion corrosion will not affect the integrity of the MWTF tanks ${ }^{35}$.

In his review of erosion-corrosion. Divine ${ }^{35}$ references data showing that as little as $0.2 \%$ chromium in a mild steel can reduce the wear rate by $80 \%$. Specifying a minimum chromium limit of $0.2 \%$. which is within the material composition range of either SA 516 or SA 537. may thus provide extra assurance of minimizing erosion-corrosion. A $0.10 \%$ range is normally defined, e.g:, a range of 0.20 to $0.30 \%$ would allow for chemistry and analytical tolerances.

\section{Effects of Hydrogen.}

- Considerations

All DSTs at Hanford contain some hydrogen ${ }^{36}$. Hydrogen, if absorbed by the metal. is known to be detrimental to $\mathrm{CS}^{37}$. Hydrogen in the MWTF will occur in two environments, the vapor zone and the liquid zone (see Figure 3). Its effects in each zone are addressed separately.

Hydrogen-induced cracking (HIC) of CS has induced fajlures of tanks and chemical equipment in the chemical process industries. HIC-resistant SA 516 . Grade 60. and SA 516. Grade 70. CS is supplied in the United States by three suppliers. The price difference between SA 537. Class 1. which is normalized, and HIC resistant SA 516. Grade 60, in the normalized condition, vacuum degassed. and 
calcium treated for sulfur inclusion shape control, an extremely clean steel is about $30 \%$. This $30 \%$ includes about $5 \%$ for HIC testing. With normalizing only. SA 516. Grade 70, is about 5\% less expensive than SA 537. Class 1.

- Vapor Zone. The hydrogen in the vapor zone is molecular hydrogen, gaseous $\mathrm{H}_{2}$. which is not a form detrimental to CS at low temperatures. Hydrogen can be properly and safely stored in CS tanks at high pressure for use in welding. The hydrogen in the vapor zone is not a concerri.

- Liquid Zone. The hydrogen in the liquid zone can be either monatomic or molecular hydrogen... When CS corrodes or when water dissociates. monatomic hydrogen (H) is produced. . This form of hydrogen, if it reaches sufficiently high concentrations, can be detrimental to CS.

- Evaluation

Divine ${ }^{38}$ also has addressed the effects of hydrogen on the MWTF tank carbon steel. His conclusions, presented below, are separated into hydrogen effects during construction and those that will occur during the 50 -year service life of the tanks.

Because the CS plates will be normalized at the steel mill and the primary tank will be PWHT after fabrication, there should be little residual hydrogen in the CS, and it should have little or no effect on the CS in the finished primary tanks ${ }^{38}$.

The hydrogen in the liquid zone can be monatomic or molecular hydrogen. The molecular hydrogen is not a concern. Because of the small amounts of monatomic hydrogen. Divine ${ }^{38}$ determined that it will not. affect the MWTF tank CS during the 50-year design Tife.

Further. evaluation at SRS of five mild steel "pillow" specimens left in waste similar to Hanford's for 13.3 years in test for hydrogen embrittlement. indicated no swelling as a result of hydrogen permeation ${ }^{39}$.

Effects of Lead.

- Considerations: "..

Parkins ${ }^{41}$ has published technical articles indicating that lead in solution affects CS corrosion. Some SSTs at Hanford have been identified as containing leads.

- Evaluation

Divine ${ }^{41}$ has addressed the effects of lead on the MWTF CS tanks. He concluded that while MWTF will be operating at temperatures far below those in which cracking can occur and the waste will have other components including inhibitors. there is a possibility that the lead concentrations in some source tanks will exceed those concentrations found earlier to cause cracking. Tanks with lead wont be treated for 10-15 years, giving time to evaluate and solve this problem. 


\section{- Considerations}

- If significant differences exist between the corrosion resistance of SA 516 and SA 537 CS. the material with the best resistance would be selected for fabrication of the MWTF tanks.

- Evaluation

Other than the work performed from 1980 to $1984^{23}$. there are no studies comparing the corrosion behavior of SA 516 and SA 537 carbon steels in caustic nitrate/nitrite solutions. Divine io states that "except for very dilute and high temperature concentrated conditions, the corrosion rates of SA 516 and SA 537 steels were low. less than 1 mpy $(25 \mu \mathrm{m} / \mathrm{y})$ and generally less than $0.5 \mathrm{mpy}$ $(12.5 \mu / y)$."

The conclusion is that as long as the tank contents are maintained within the limits defined by the Hanford Tark Corrosion Specifications'. there will be no significant difference of corrosion between the two alloys. There appears to be some difference in the response of each alloy to the various components but. within the operating limits; it is of no significance.

Supplemental Requirements

Supplemental requirements to the ASKE SA 516. Grace 70 material specification that are needed for design and/or fabrication to meet ASME Code requirements will be identified by the certificate holder(s) contracted to perform the work. In the preparation of this report. all the Supplementary Requirements listed for SA 20. Specification for General Requirements for Steel Plate for Pressure Vessels. Clad Steel. Plates. were reviewed to identify any of the requirements that should be involved because of the special features of the MilF tonk operations that might be outside the considerations of the ASME certificate holder. If supplementary requirements are invoked, it must be known exactly what they will do for improving the performance of the tanks. In many cases. doing things that make the material "better." "cleaner." "more forgiving." do not directly affect performance and may not be cost-effective. Addition requirements identified in this review are given below.

Added Chemistry Requirements. Chromium will be added to the ASME SA 516 plate material melt specification for erosion control or prevention. A small addition of Ehromium. between 0.2 and $0.3 \%$, will increase erosion corrosion resistance by a factor of $3^{22}$. To insure adequate chromium in the steel for erosion control. limits on chromium content shall be a minimum of $0.2 \%$ and the maximum given in SA 20.

If mechanical test data (e.g. charpy test, drop-weight test, fracture toughness test. grain size, or other metallurgical information are required in the future to deal with operational considerations. archived tank plate materials are being supplied by the certificate holder to the owner which can be tested or examined to provide the required information. 
In addition to the supplemental requirements in SA 20. the following requirements must be specified.

- Test reports to be sent to buyer

- Heat number and chemistry (mill certifications)

- Tensile, yield. elongation, and ultimate

… Charpy V-notch

$\because$ Drop-weight test and nil-ductility transition temperature determination

All test reports shall be documented in a supporting document.

- Test samples, coupons. specimens - All test coupons, samples, tensile test samples. Chärpy $V$-notch. drop-keight, metallographs. metallurgical samples. and grain-size specimens shall be sent to the buyer for documentation ond archiving.

- Manufacture - Steel-making practice - The steel shall be killed and shall conform to the fine austenitic grain-size requirement of 5 or finer of Specification A 20/A 201.

- Heat treatment - All plate shạll be thermally treated by normalizing.

Chemical requirements - The steel shall conform to the chemical requirements shown in Table 2. except for chromium, which shall be as stated in supplementary requirement 519 .

- Mechanical Requirements

- The material as represented by the tension-test specimens shall conform to the requirements shown in Table 3.

- These supplementary requirements shall be updated before purchase of material. .

- Surface Texture - Mill scale removal is not required from the mill. 14 i 11 scale removal shall occur after tonk fabrication and after PWHT.

\section{CONCLUSIONS}

ASME SA.516. Grades 60 and 65, are eliminated from the selection process in favor of Grade 70 because the higher ultimate strength of the Grade 70 is preferred for design purposes. The choice is clearly between the remaining two candidates, SA 516. Grade 70, and SA 537. Class 1.

ASME SA 537. ClaSS 1. CS is normalized aS a part of the specification. ASME SA 516. Grade 70. CS can be obtained either with or without normalization. Because normalized material is the choice, given the size of the order for the MWTF tanks, there is little likelihood that a mill or jobber 
error would occur that would result in shipment of non-normalized material. so there is no reason to select SA 537 on the basis of this concern.

The chemical composition data in Table 2 do not provide clear reasons for either a yield or an NDT difference between the two candidate alloys. The code specifies the minimum values for each steel for use in design. and the mill must guarantee material that will meet the minimum requirements. However. for the actual material used. there probably will be no distinction between one material and the other.

The corrosion resistance of both alloys considered is very similar for each of the types of corrosion reviewed. The SA 537 alloy may be slight more resistant to SCC than the SA 516 alloy, but this conclusion is not substantiated by all the data. Selection of the alloy does not depend on corrosion-resistance properties.

ASME SA 537. Class 1. CS has slightly better (lower) NDT properties than ASME SA 516. Grade 70. However. both steels are acceptable for MWTF fabrication and operation in regard's to NDT properties: the selection of the preferred steel is not influenced by this property.

Both ASME SA 516. Grade 70, and SA 537. Class 1, materials have performed satisfactority in the Hanford and/or SRS DSTS for the past 24 years. Materials today are metallurgically much better then those used at Hanford or SRS 20 years ago.

ASME SA 537. Closs 1. typically costs about 5\% more than SA 516. Grade 70. normalized CS.

\section{RECOMMENDATIONS}

Evaluation of all of the above design requirements, material properties. corrosion considerations, and costs indicates that normalized ASME SA 516. Grade 70, meets minimum technical requirements: it should be the material of choice:

\section{REFERENCES}

1. B. D. Groth, Multi-Function Waste Tank Facility Design Criteria. Westinghouse Hanford Company Report WHC-SD-W236-FDC-001. Rev. 1. Richland. Washington. 1993

2. N. W. Kirch. Technical Basis for Waste Tank Corrosion Specification. Rockwell Hanford Operations Report WHC-SD-WM-TI-150, Richland. Washington, 1984.

3. W. C. Carlos. Failure Mode Analys is of the Multi-Function Waste Tank Facility Tanks, Westinghouse Hanford Company Report WHC-SD-W236A-ES008. Richland. Washington. 1994

4. J. A. Ryan. Design Assessment Review. Hanford High-Level Waste Tanks. Westinghouse Hanford Company Report WHC-SD-WM-ER-119. Richland, Washington, 1991 
5. B. M. Hanton. Tank Farm Surveillance and Waste Status Sumary Report for November 1993. Westinghouse Hanford Company Report WHC-EP-0182-68. Richland. Washington. 199.4

6. J. A. Donovan. Material Aspects of SRP Waste Storage - Corrosion and Mechanical Failure. Savannah River Laboratory Report DP-1476. Aiken. South Carolina. 1977

7. D. C. Meess. DOE High-Level Waste Task Force Corrosion Technology Exchange, West Valley. Nuclear Services, West Vảlley. New York. 1991

8. ASME. American Society of Mechanical Engineers Boiler \& Pressure Vessel Code: Section III. American Society of Mechanical Engineers. New York. New York. 1992

9. ASME. American Socjety of Mechanical Engineers Boiler \& Pressure Vessel code. Section II. American Society of Mechanical Engineers.

New York. New York. 1992

10. P. A. LoBel10. Radioactive Waste Storage Tanks. CBI Services. Inc.. Fremont. California, 1994

11. ASKE. American Society of liechanical Engineers Boiler \& Pressure Vessel code. Section IX. QN 422. American Society of Mechanical Engineers. New York. New York. 1992

12. E. L. Moore. Stress Corrosion Cracking of A515 Grade 60. Carbon Steel. Atlantic Richíield Hanford Company Report ARH-1290. Richland. Washington. 1971

13. R. E. Mesloh, Sumary Report on Failure Investigation of Ashland 0il Tank No. 1338 at Floreffe. Pennsylvania. Battelle Memorial Institute. Columbus, Ohio, 1988

14. R. S. Ondrejcin. S. P. Rideout, and J. A. Donovan, "Control of Stress Corrosion Cracking in Storage Tanks Containing Radioactive Waste." Nuclear Technology. 44(1979): p. 297-306.

15. E. 0. Weiner. Structural Design Requirements for Synthesis for the MWTF Waste Tanks, Westinghouse Hanford Company Report WHC-SD-W236A-ER-004. Richland. Washington. 1993

16. J. R. Eaton, Electrons, Neutrons and Protons in Engineering. (New York. NY: Pergamon Press, 1966)

17. G. R. Caskey, Potential Radiation Damage - Storage Tanks for Liquid Radioactive Waste. Westinghouse Savannah River Company Report WSRC-TR92-350. Savannah River Technology Center. Aiken, South Carolina, 1992

18. R. E. Westerman. Annual Report - FY 1986. Corrosion Behavior of A216 Grade WCA Mild Steel and Ti Grade 12 Alloy in Hydrothermal Brines. Pacific Northwest Laboratory Report PNL/SRP-6221. Richland. Washington. 1986

19. W. C. Cârlos. PUREX Dangerous Wáste Tank Radiation Compatibility 
Assessment. Westinghouse Henford Company Report WHC-SD-CP-EV-015. Richland. Wastington. 1993

20. J. R. Divine. W. M. Bowen. D. B. Mackey. D. J. Bates, and K. H. Pool, Prediction Equations for Corrosion Rates of A-537 and A-516 Steels in Double Shell Slurry. Future PUREX. and Manford Facilities Wastes. Pacific Northwest Laboratory Report PNL-5488. Richland. Washington, 1985

21. M. G. Fontana and N. D. Green. Corrosion Engineering. (New York. NY: MCGraw-Hill Publishing Company. 1978)

22." L. P. Costas. Stress Corrosion Cracking of Carbon Steel in Simulated Waste Solutions. Savannah River Laboratory Report OP-1023. Aiken. South Carolina. 1966

23. R. F. Máness, Mild Steel Stress Corrosion Cracking. Battelle Northwest Laboratory Report BWWL-CC-632. Richland. Washington. 1966

24. W. C. Carlos and J. P. Hauptimann. Comparison of Desion. Materials. Fabrication and Waste Environments of the Hanford Site and River Plant single She 17. Tanks. Westinghouse Hanford Company Report WHiC-SD-WM-SMSL015. Richland, Washington. 1993

25. R. P. Anantatmula. E. B. Schwenk. and M. J. Danielson. Characterization of the Corrosion Behavior of the Carbon Steel Liner in Hanford Site Single-She?7 Tanks. Westinghouse Hanford Company Report WHC-EP-0772. Rev. 0. Richland. Washington. 1994

26. P. E. Zápp, and D. T. Hobbs. Inhibiting Pitting Corrosion in Carbon Steel Exposed to Dilute Radioactive Waste Slurries. CORROSION/92. Paper * No. 98, (Houston. TX: NACE Internationa?. 1992).

27. E. C. Pitzer Corrosion Tests - SAE $1010 \mathrm{Mi}$ ld Steel in Synthetic Metal Waste Solutions. General Electric Company Report HW-24136. Richland. Washington. 1952

28. N. Endow, A Laboratory Study of the Extent of Pitting and General Corrosion of SAE 1010 Steel in Simulated Neutralized PUREX Process Waste. General Electric Company Report HW-32734. Richland. Washington. 1954

29. D. F. Bickford. J. W. Congdon, and S. B. Oblath, Electrochemical Probe of High-level Radioactive Waste Tanks Containing Sludge and Precipitates I. E. duPont de Nemours and Co. Report DP-MS-86-178. Aiken. South Carolina, 1987

30. R. J. Jacko, and R. H. Kunig. First Examination. West Valley Nuclear Services Tank 80-1 Corrosion Specimens After Nine Months Exposure. Westinghouse Science and Technology Center. Pittsburgh. Pennsylvania. 1990

31. E. Escalante, Personal Communication. National Institute of Standards and Technology (NIST). Gaithersberg. Maryland. 1994 
32. D. T. Hobbs, Hydroxide Depletion in Waste Storage Tanks by Reaction with Carbon Dioxicie. DuPont. Savannah River Laboratory Report DPST-85-846. Aiken. South Carrolina. October 1985

33. D. T. Hobbs, Absorption of Carbon Dioxide in Waste Tànks. DuPont. Savannah River Laboratory Report DPST-87-596. Aiken. South Carolina. September 1987

34. A. P. Larrick. W. C. Carlos, and E. R. Cramer. Corrosion Control in the Vapor Zonie at the Multi-Function Waste Tank Facility Tanks. Westinghouse Hanford Company Report WHC-SD-W236A-ES-006. Richland. Washington, 1994

35. J. R. Divine. U. F. Brenm. W. C. Carlos, and A. P. Larrick. Multi-Function taste Tank Facjlity Tank Erosion-Corrosion Allowance Recommendations. Kestinghouse Hanford Company Report WHC-SD-W236A-ES-002. Richland. Wâshington, 1994

36. J. S. Garfield, Maximum Anticipated Hydrogen Concentrations in Underground Tank Atmospheres from Radiolysis of Water. Atlantic Richfield Hanford Company. Report ARH-CD-267. Richland: Washington, 1975

37. M. Smialowski. Hyórogen in Steel. (New York. NY: Pergamon Press, 1962)

38. J. R. Divine. W. F. Brehm. W. C. Carlos, and A. P. Larrick. The Effects of Hydrogen on Multi-function Waste Tank Facjlity Carbon Steels. Westinghouse Hanford Company Report WHC-SD-W236A-ES-004. Richland. Washington, 1994

39. J. A. Donovan. Corrosion Specimen in Tänk 15. Savannah River Laboratory Report DPST-74-560. Aiken. South Carolina, 1974

40. R. N. Parkins and M. J. Humphries. "Stress Corrosion Cracking of Mild Steels in Sodium Hydroxide Solutions Containing Various Additional Substances." Corrosion Sciences. 7(1966): p. 747-760.

41. J. R. Divine, W.F. Brehm, W. C. Carlos, and A. P. Larrick. The Effects of Lead on Multi-Function Waste Tank Facility Carbon Steels. Westinghouse Henford Company Report WHC-SD-W236A-ES-005, Richland. Washington, 1994

42. M. Kupinski. S. Chandra. P. R. Habicht, and T. C. Esselman. Analysis of Piping Components Subject to Erosion/Corrosion at Millstone Unit 2. ASME. PVP-Volume 259 (1993). Codes and Standards in a Global Environment. Pp. 209-216

43. AWWA, "AWWA Standard for Welded Steel Tanks for Water Storage," ANSI/AWWA D100-79. American Water Works Association. Denver. Colorado.
1979

44. D. L. Becker. Accelerated Safety Analysis Structural Analysis Phase I Structural Sensitivity Evaluation of SST and DST Storage Tanks. Westinghouse Hanford Company Report WHC-SD-WM-SARR-012. Richiand. Washington, 1994 
45. M. R. Elmore. Assessment of Potential for Increased Pitting Corrosion of Hanford DST Containing Dilute Nitrate Wastes. Pacific Northwest Laboratory Report DST-92-0301A. Richland. Washington. 1992

46. R. F. Maness. Stress Corrosion Cracking of Mild Steel in Nitrate Solutions. General Electric Company Report HW-78168. Richland. Washington. 1963 
TABLE 1

SUMMARY LISTING OF DOE CARBON STEEL HIGH-LEVEL-WASTE STORAGE TANKS ${ }^{4,7,17}$

(Page 1 of 2)

\begin{tabular}{|c|c|c|c|c|c|c|c|c|}
\hline ASTM/ASME Specification & $\begin{array}{c}\text { Plate } \\
\text { Condition } \\
\end{array}$ & PWHT & $\begin{array}{c}\text { Year Steel was } \\
\text { Introduced }\end{array}$ & DOE site & $\begin{array}{l}\text { Year Tank } \\
\text { Was Built }\end{array}$ & $\begin{array}{c}\text { Tank Type } \\
\text { (SST or DST) } \\
\end{array}$ & Tank Farm & $\begin{array}{c}\text { Number of } \\
\text { Tanks }\end{array}$ \\
\hline A $7-1939$ & $A-R$ & No & \multirow[t]{2}{*}{1901} & Ulanford & 1943 & SST & $B, C_{U}, T$, & $\begin{array}{l}12 \text { each, } \\
48 \text { tanks }\end{array}$ \\
\hline A $7-1939$ & $A-R$ & No & & Hanford & . 1946 & SST & $B X$ & 12 tanks \\
\hline
\end{tabular}

A 7 discontinued - replaced by A 36 in $1960^{\circ "}$

\begin{tabular}{|c|c|c|c|c|c|c|c|c|}
\hline A $201-1961 \mathrm{~T}$, Grade A & $A=R$ & No & \multirow[t]{2}{*}{1949} & Manford & 1963 & SST & $A X$ & 4 tanks \\
\hline A 201-1964, Grade A & N & Yes & & West Valley & 1964 & DST* & & 2 tanks \\
\hline
\end{tabular}

A 201 discontinued before 1968 - replaced by A 515 and A 516

\begin{tabular}{|l|l|l|l|l|l|l|l|l|}
\hline A $212-1957 T$, Grade B & A-R & No & 1937 & Savannah River & 1961 & SST, Type IV & H Area & 4 tanks. \\
\hline
\end{tabular}

\begin{tabular}{|l|c|c|}
\hline \multicolumn{3}{|c|}{ A 212 discontinued before 1968 - replaced by A 515 and } \\
\hline A 283-1946T, Grade C & A-R & No \\
\hline A 283-1949T, Grade B & $A-R$ & No \\
\hline A 283-1946T, Grade B & A-R & No \\
\hline A 283-1949T, Grade B & A-R & No \\
\hline A 283-1952T, Grade A or B & A-R & No \\
\hline
\end{tabular}

6 in 1964

A 283 is currently not an ASME material - it was ASME Code in 1967 and 1971

\begin{tabular}{|c|c|c|c|c|c|c|c|c|}
\hline A $285-1946$, Grades $B$ and $C$ & $A-R$ & No & \multirow[t]{5}{*}{1946} & Hanford & 1948 & SST & $8 Y$ & 12 tanks \\
\hline \multirow[t]{2}{*}{ A $285-1950$, Grade B } & \multirow[t]{2}{*}{$A-R$} & \multirow[t]{2}{*}{ No } & & \multirow[t]{2}{*}{ Savannah River } & 1953 & SST, Type I & $\begin{array}{l}\text { F Area } \\
\text { H Area } \\
\end{array}$ & $\begin{array}{l}8 \text { tanks } \\
4 \text { tanks }\end{array}$ \\
\hline & & & & & 1956 & SST, Type 11 & H Area & 4. tanks \\
\hline A 285-1952aT, Grades B and C & $A-R$ & No & & Manford & 1954 & SST & A & 7 tanks \\
\hline A $285.1954 \mathrm{~T}$, Grade B & $A-R$ & No & & Savannah River & 1958 & sst, Type IV & F Area & 4 tanks \\
\hline
\end{tabular}


TABLE 1

SUMMARY LISTING OF DOE CARBON STEEL HIGH-LEVEL-WASTE STORAGE TANKS $4,7,17$

(Page 2 of 2 )

\begin{tabular}{|c|c|c|c|c|c|c|c|c|}
\hline ASTM/ASME Specification & $\begin{array}{c}\text { Plate } \\
\text { Condition } \\
\end{array}$ & PWIIT & $\begin{array}{c}\text { Year steel was } \\
\text { Introduced } \\
\end{array}$ & DOE site & $\begin{array}{l}\text { Year Tank } \\
\text { Was Built } \\
\end{array}$ & $\begin{array}{c}\text { Tank TYpe } \\
\text { (SST of OST) } \\
\end{array}$ & Tank Farm & $\begin{array}{c}\text { Number of } \\
\text { Tanks }\end{array}$ \\
\hline A $515-1965$, Grade 60 & N & Yes & \multirow[t]{2}{*}{1964} & Hanford & 1970 & DST & AY & 2 tanks \\
\hline A $515-1969$, Grade 60 & N & Yes & & Manford & 1977 & DST & $A z$ & 2 tanks \\
\hline \multirow[t]{2}{*}{ A $516-1964$, Grade 70} & \multirow{4}{*}{$\begin{array}{c}\text { Before } 1974 \\
A-R \\
\text { and } \\
\text { After } 1974 \\
N\end{array}$} & \multirow[t]{2}{*}{$\therefore$ Yes } & \multirow[t]{5}{*}{1984} & \multirow[t]{2}{*}{ Savannah River } & 1972 & \multirow[t]{4}{*}{ DST, Type 111} & \multirow[t]{2}{*}{ F Area } & 2 tanks \\
\hline & & & & & 1978 & & & 4 tanks \\
\hline \multirow[t]{2}{*}{ A $516-1964$, Grade 70} & & \multirow[t]{2}{*}{ Yes } & & \multirow[t]{2}{*}{ Savannah River } & 1970 & & \multirow[t]{2}{*}{ H Area } & 4 tanks \\
\hline & & & & & 1977 & & & 3 tanks \\
\hline A $516-1972$, Grade 65 & $N$ & Yes & & Manford & 1978 & DST & sY & 3 tanks \\
\hline A 537-1974a, Class 1 & $N$ & Yes & \multirow[t]{5}{*}{1965} & Hanford & $1979^{\circ}$ & DST & AW & 6 tanks \\
\hline A $537-1975$, Class 1 & $\mathrm{~N}$ & Yes & & Manford & 1981 & DST & AN & 7 tanks \\
\hline A $537-1979$; Class 1 & $N$ & Yes & & Hanford & 1986 & DST & AP & 8 tanks \\
\hline A $537-1974$, Class 1 & N & Yes & & Savannah River & 1980 & \multirow[t]{2}{*}{ DST, Type III } & F Area & 4 tanks \\
\hline A $537-1974$, Class 1 & N & Yes & & $\begin{array}{c}\text { Savannah River } \\
.\end{array}$ & 1981 & & 4 Area & 10 tanks \\
\hline
\end{tabular}

PWHT $=$ Post-weld heat treated

SST = Single-shell tank

DST = Double-shell tank

$A-R=$ As-rolled

$N=$ Normalized

*A SST sitting in a steel pan with walls $4 \mathrm{ft}$ high 
TABLE 2

COMPOSITION OF CARBON STEELS BEING EVALUATED

\begin{tabular}{|c|c|c|c|c|c|c|c|c|c|c|c|c|}
\hline \multirow{2}{*}{$\begin{array}{c}\text { Material, } \\
\text { Grade \& } \\
\text { Class }\end{array}$} & \multicolumn{12}{|c|}{ Composition, wt $\%^{1}$} \\
\hline & $\begin{array}{c}C \\
\max \\
\end{array}$ & $\mathrm{Mn}$ & $\begin{array}{c}P \\
\max \\
\end{array}$ & $\begin{array}{r}S . \\
\max \\
\end{array}$ & $\mathrm{Si}$ & $\begin{array}{r}\text { Cu } \\
\max \\
\end{array}$ & $\begin{array}{l}\mathrm{Ni} \\
\mathrm{max} \\
\end{array}$ & $\begin{array}{c}\mathrm{Cr} \\
\max \\
\end{array}$ & $\begin{array}{l}\text { Mo } \\
\max \\
\end{array}$ & $\begin{array}{c}V \\
\max \\
\end{array}$ & $\begin{array}{l}\mathrm{Nb} \\
\max \\
\end{array}$ & $\begin{array}{c}0 \\
\max \\
\end{array}$ \\
\hline \multicolumn{13}{|c|}{ A 516-1986/1992, Grade 70 , latest } \\
\hline Under $1 / 2 "$ & 0.27 & $0.79 / 1.30$ & 0.035 & 0.040 & $0.13 / 0.45$ & $0.43^{*}$ & $0.43^{*}$ & $0.34^{*}$ & $0.13^{\star}$ & $0.04 \star$ & $0.03^{*}$ & $\mathrm{NS}^{\#}$ \\
\hline $1 / 2^{11}$ to $2^{\prime \prime}$ & 0.28 & $0.79 / 1.30$ & 0.035 & $0 \lcm{040}$ & $0.13 / 0.45$ & $0.43^{*}$ & $0.43^{*}$ & $0.34 *$ & $0.13 *$ & $0.04^{*}$ & $0.03 *$ & $\mathrm{MS}^{\#}$ \\
\hline \multicolumn{13}{|c|}{$\begin{array}{l}\text { Special HIC-Resistant A } 516 \text { with inclusion shape control } \\
\text { A 516, Grade } 70 \text {, Class A }\end{array}$} \\
\hline Under $1 / 3$, & 0.27 & $0.79 / 1.3$ & 0.003 & 0.001 & $0.13 / 0.45$ & $0.43^{*}$ & $0.43^{*}$ & $0.34_{4} *$ & $0.13^{\star}$ & $0.04 *$ & $0.03 *$ & 0.002 \\
\hline$y_{211}$ to $2^{11}$ & 0.28 & $0.79 / 1.3$ & 0.008 & 0.001 & $0.13 / 0: 45$ & $0.43 *$ & $0.43^{*}$ & $0.34 *$ & $0.13^{*}$ & $0.04 *$ & $0.03^{*}$ & 0.002 \\
\hline \multicolumn{13}{|c|}{ A 516, Grade $70, C l a s s B^{2}$} \\
\hline Under $1 / 2 "$ & 0.27 & $0.79 / 1.3$ & 0.010 & 0.002 & $0.13 / 0.45$ & $0.43 *$ & $0.43^{\star}$ & $0.34 *$ & $0.13^{*}$ & $0.04 *$ & $0.03 *$ & 0.003 \\
\hline$y_{2}^{\prime \prime}$ to $2^{\prime \prime}$ & 0.28 & $0.79 / 1.3$ & 0.010 & 0.002 & $0.13 / 0.45$ & $0.43 *$ & $0.43^{*}$ & $0.34 *$ & $0.13^{*}$ & $0.04^{*}$ & $0.03 *$ & 0.003 \\
\hline \multicolumn{13}{|c|}{ A $537-1986 / 1992$, Class 1} \\
\hline Under $11 / 2^{11}$ & 0.24 & $0.64 / 1.46$ & 0.040 & 0.040 & $0.13 / 0.55$ & 0.38 & 0.28 & 0.29 & 0.09 & $0.04 *$ & $0.03 *$ & NS \\
\hline
\end{tabular}

'Product analysis

'Luken Steel Company classification for HIC-resistant steels

$C=$ carbon

$\mathrm{Ni}=$ nickel
$M n=$ manganese

$\mathrm{Cr}=$ chromium
$P=$ phosphorus $S=$ sulfur Mo $=$ molybdenum $V=$ vanadium
*ASTM A20 specified "NS $=$ Not specified

$S i=$ silicon

$\mathrm{Nb}=$ niobium

(columbium)
$\mathrm{Cu}=$ copper

$0=$ oxygen 
TABLE 3

MWTF TANK CARBON STEEL MATERIAL SELECTION MATRIX, (Page 1 of 2)

\begin{tabular}{|c|c|c|c|}
\hline MWTF Tank Requirements & $\begin{array}{l}\text { ASME SA } 516-86 \\
\text { Grade } 70 \\
\end{array}$ & $\begin{array}{l}\text { ASME SA } 537-86 \\
\text { ClasS } 1 \\
\end{array}$ & $\begin{array}{l}\text { Comments or } \\
\text { References }\end{array}$ \\
\hline ASME section 11 approved material? & Yes & Yes & Reference 8 \\
\hline Supplementary or special steel composition or processes? & \multicolumn{2}{|c|}{$\begin{array}{l}\text { - Plate must be ultrasonic tested (UT) for } \\
\text { internal laminations. No laminations allowed } \\
\text { within } 8 \text { inches }(52 \mathrm{~cm}) \text { of plate edge. } \\
\text { - No weld repair allowed on plate within } 8 \text { in. }(52 \\
\mathrm{cm}) \text { of edge }\end{array}$} & $\begin{array}{l}\text { ASME SA } \\
\text { Specifications }\end{array}$ \\
\hline Availability in plate thicknesses produced between $z^{\prime \prime}$ and $1 y^{n}$ ? & Yes & Yes & $\begin{array}{l}\text { Vendor } A \\
\text { Vendor } B\end{array}$ \\
\hline $\begin{array}{l}\text { Heat treatment: Material can be provided in the normolized } \\
\text { condition? }\end{array}$ & $\gamma_{\mathrm{es}}$ & res & $\begin{array}{l}\text { Vendor A } \\
\text { Vendor B }\end{array}$ \\
\hline Constructability & Acccptable & Acceptablc & Reference 10 \\
\hline 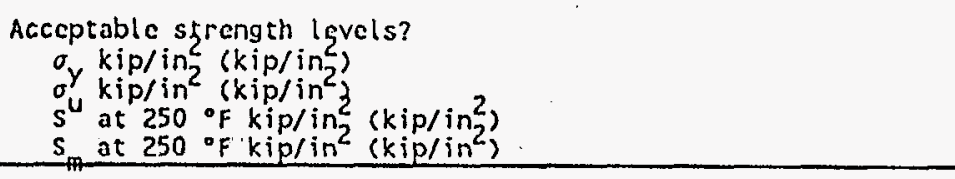 & $\begin{array}{r}\text { Yes } \\
38.0 \\
70.0 \\
17.5 \\
22.8 \\
\end{array}$ & $\begin{array}{r}Y c s \\
50.0 \\
70.0 \\
17.35 \\
23.05 \\
\end{array}$ & Refercnce 9 \\
\hline $\begin{array}{c}\text { Weldability? } \\
\text { p number }\end{array}$ & $\begin{array}{l}\text { Acceptabie } \\
P=1 G-2\end{array}$ & $\begin{array}{c}\text { Acceptable } \\
P-1 G-2 \\
\end{array}$ & Reference 11 \\
\hline $\begin{array}{l}\text { Post-weld heat treatment } \\
\therefore \text { Stress relief acceptable } \\
\text { Impact of stress relief on the strength (1 cycle) }\end{array}$ & $\begin{array}{c}\text { res } \\
\text { Accoptable } \\
\end{array}$ & $\begin{array}{c}\text { Yes } \\
\vdots \\
\text { Acceptable }\end{array}$ & $\begin{array}{l}\text { Reference } 6, \\
\text { Reference } 12\end{array}$ \\
\hline $\begin{array}{l}\text { Acceptable brittle fracture during the } 50 \text {-year design life? } \\
\text { During the construction period? } \\
\text { Nil-ductility transition temperature (NDT) }\end{array}$ & $\begin{array}{c}\text { Yes } \\
\text { Yes } \\
-12 \text { to }-46^{\circ} \mathrm{C} \\
\left(+10 \text { to }-500^{\circ} \mathrm{F}\right) \\
\end{array}$ & $\begin{array}{c}\text { Yes } \\
\text { Yes } \\
-23 \text { to }-57^{\circ} \mathrm{C} \\
\left(-10 \text { to }-70^{\circ} \mathrm{F}\right) \\
\end{array}$ & Reference 8 \\
\hline Has material acceptable fatigue propertics? & Yes & Yes & Reference 15 \\
\hline Resistant to expected radiation levels for 50 years? & Yes & Yes & Reference 17 \\
\hline $\begin{array}{l}\text { Price ratio } \\
\text { Hydrogen-induced cracking (HIC) resistant Class A }\end{array}$ & $\begin{array}{r}1.0 \\
1.05 \text { to } 1.5 \\
\end{array}$ & $\begin{array}{l}1.05 \\
\text { N/A }\end{array}$ & $\begin{array}{l}\text { Vendor } \mathbf{B} \\
\text { Vendor } \mathrm{A}\end{array}$ \\
\hline
\end{tabular}


TABLE 3

MWTF TANK CARBON STEEL MATERIAL SELECTION MATRIX. (Page 2 of 2 )

\begin{tabular}{|c|c|c|c|}
\hline MWTF Tank Requirements & $\begin{array}{c}\text { ASME SA 516-86 } \\
\quad \text { Grade } 70 \\
\end{array}$ & $\begin{array}{c}\text { ASME SA 537-86 } \\
\text { Class } 1\end{array}$ & $\begin{array}{c}\text { Comments or } \\
\text { References }\end{array}$ \\
\hline \multicolumn{4}{|c|}{ Material Corrosion Properties } \\
\hline $\begin{array}{l}\text { Has material performed satisfactorily in U.S. Department of Energy } \\
\text { (DOE) double-shell tanks (DST)? }\end{array}$ & Yes, since 1974 & Yes, since 1980 & $\begin{array}{l}\text { Reference } 4 \\
\text { Reference } 5 \\
\end{array}$ \\
\hline $\begin{array}{l}\text { Mects functional design criteria (FDC) general corrosion rate } \\
\text { criteria of }<1 \text { mil/year? }\end{array}$ & Ycs & Yes & Reference 20 \\
\hline $\begin{array}{l}\text { Resists stress-corrosion cracking (SCC) with proper inhibiting per } \\
\text { Hanford waste tank corrosion specifications? }\end{array}$ & Ycs & res & $\begin{array}{l}\text { Reference } 14 \\
\text { Reference } 2 \\
\text { Reference } 20 \\
\end{array}$ \\
\hline $\begin{array}{l}\text { Resists pitting with proper inhibiting per Hanford waste tank } \\
\text { corrosion specifications? }\end{array}$ & Yes & Yes & Reference $20^{\circ}$ \\
\hline Vapor zone corrosion & Requires control & Requires control & Reference 34 \\
\hline Has material acceptable erosion corrosion rates? & $\begin{array}{c}\text { Corrosion allowance } \\
\text { requircd }\end{array}$ & $\begin{array}{c}\text { Corrosion all owance } \\
\text { required }\end{array}$ & Reference 35 \\
\hline Is material produced HIC resistant? & Yes & No & Vendor B \\
\hline Does hydrogen affect selection of the CS? & No & No & Reference 38 \\
\hline Does lead affect selection of CS for these tanks? & No & No & Reference 41 \\
\hline
\end{tabular}




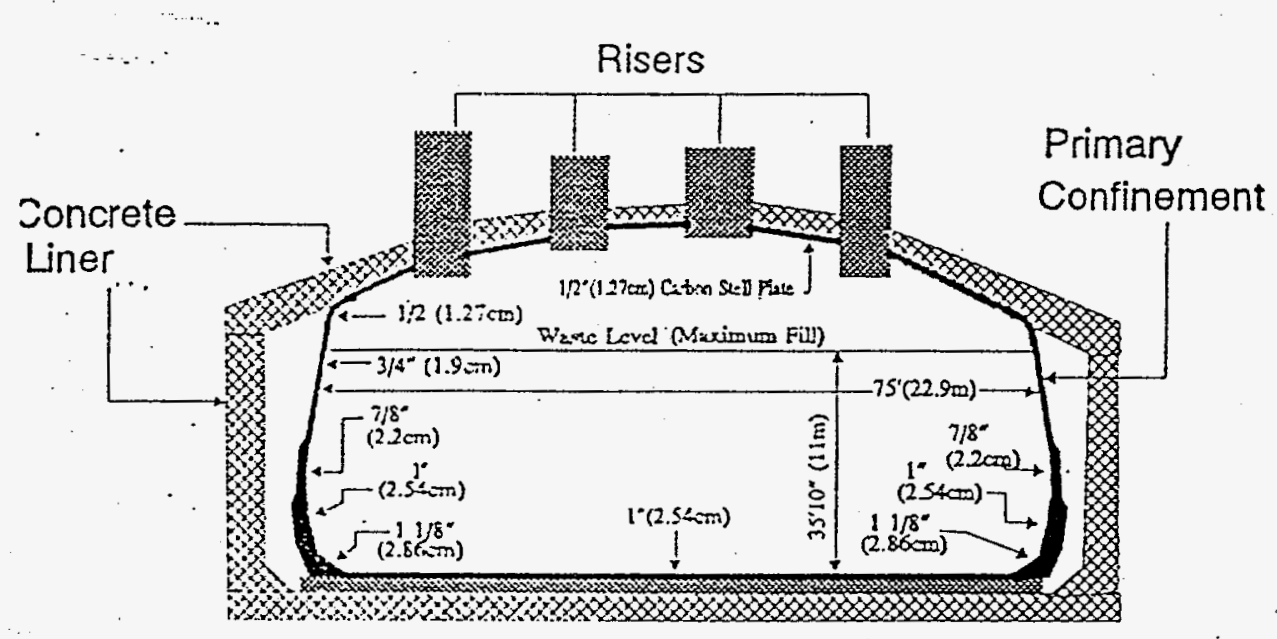

Figure 1

MWTF Tank Carbon Steel Plate Thickness -Conceptual

Risers

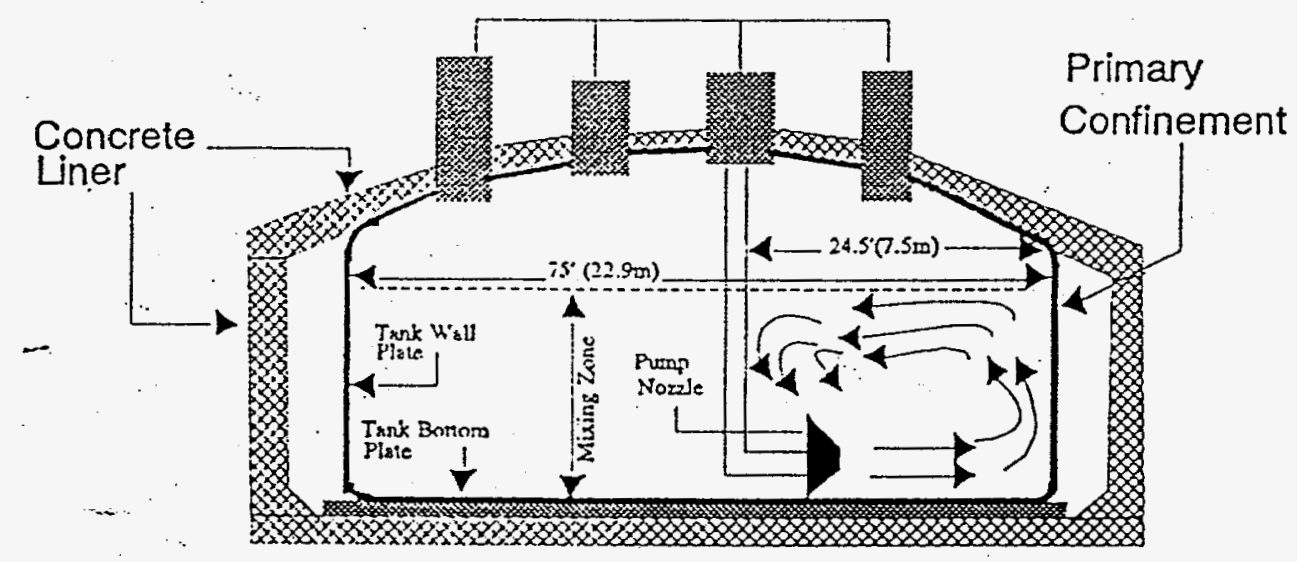

Figure 2

MWTF Tank Flow Pattern Jet Velocity 


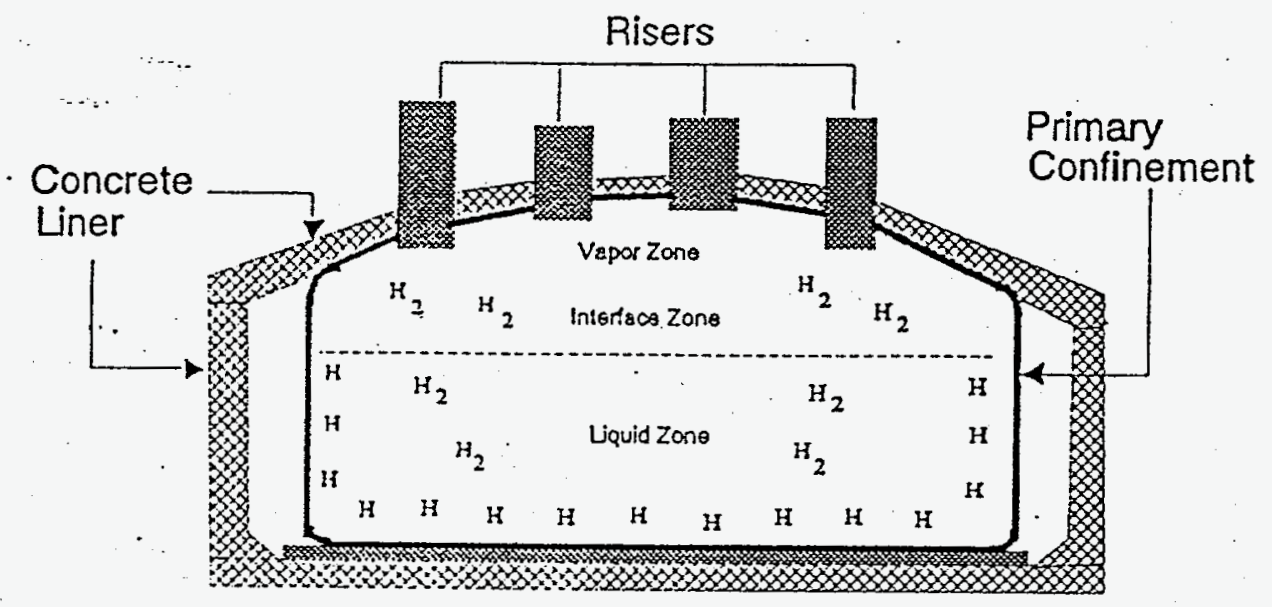

Figure 3

Carbon Steel Waste Tank Hydrogen Environments

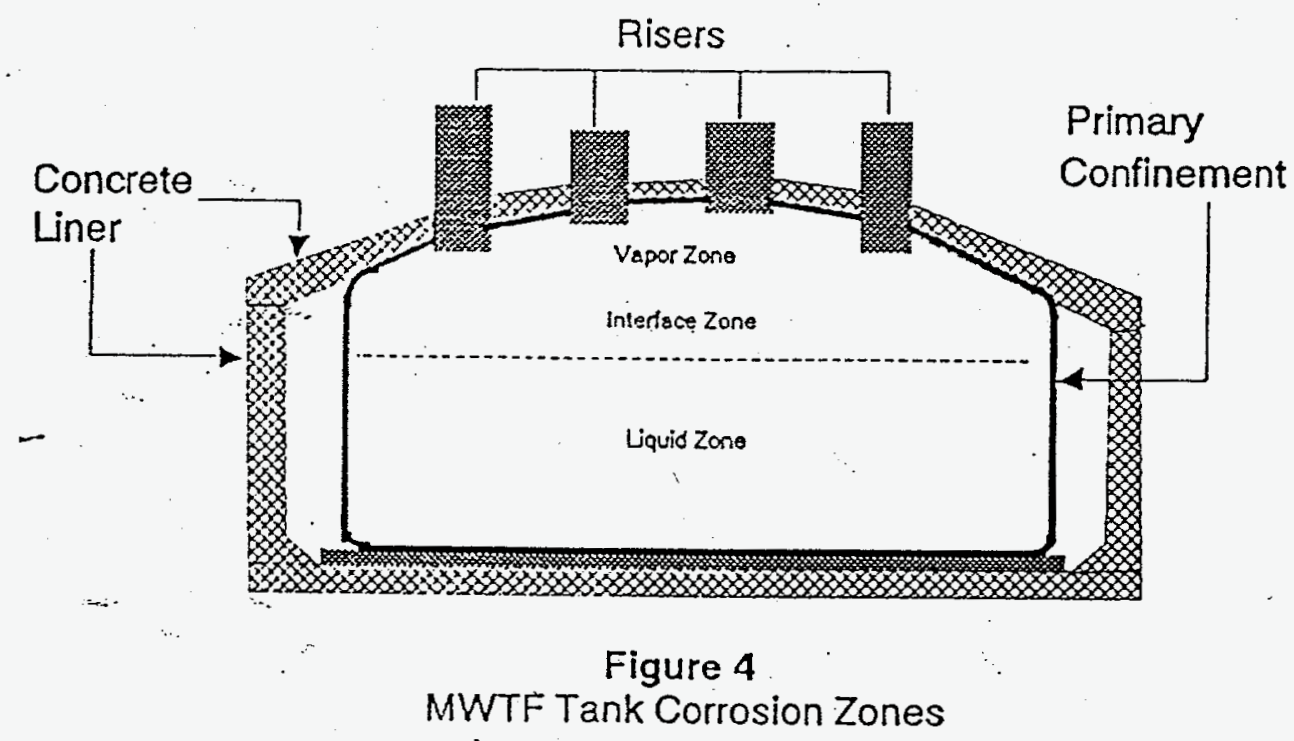


SEPARATE LIST OF TYPED CAPTIONS FOR FIGURES 
FIGURE 1 - MWTF Tank Carbon Steel

Plate Thickness - Conceptual. 
FIGURE 2 - MWTF Tank Flow Pattern Jet Velocity. 
FIGURE 3 - Carbon Steel Waste Tank

Hydrogen Environments. 
FIGURE 4 - MWTF Tank Corrosion Zones. 